\title{
Muscarinic Regulation of Dendritic and Axonal Outputs of Rat Thalamic Interneurons: A New Cellular Mechanism for Uncoupling Distal Dendrites
}

\author{
J. Julius Zhu ${ }^{1,2}$ and Paul Heggelund ${ }^{1,3}$ \\ ${ }^{1}$ Department of Cell Physiology, Max-Planck-Institute for Medizinische Forschung, Heidelberg D-69120, Germany, ${ }^{2}$ Cold \\ Spring Harbor Laboratory, Cold Spring Harbor, New York 11724, and ${ }^{3}$ Department of Physiology, University of Oslo, \\ N-0317 Oslo, Norway
}

Inhibition is crucial for sharpening the sensory information relayed through the thalamus. To understand how the interneuron-mediated inhibition in the thalamus is regulated, we studied the muscarinic effects on interneurons in the lateral posterior nucleus and lateral geniculate nucleus of the thalamus. Here, we report that activation of muscarinic receptors switched the firing pattern in thalamic interneurons from bursting to tonic. Although neuromodulators switch the firing mode in several other types of neurons by altering their membrane potential, we found that activation of muscarinic subtype 2 receptors switched the fire mode in thalamic interneurons by selectively decreasing their input resistance. This is attributable to the muscarinic enhancement of a hyperpolarizing potassium

The thalamus relays sensory information from the periphery to cortex in a state-dependent manner (Sherman and Guillery, 1996). In an awake, attentive state, thalamic neurons fire tonic action potentials, and the transmission of sensory inputs is relatively faithful. During slow-wave sleep, thalamic cells resume a rhythmic burst-firing pattern, which allows only salient sensory inputs to be amplified and transmitted. Thalamic inhibition, provided mainly by GABAergic cells in the reticular nucleus and local interneurons in the dorsal nuclei, modulates the sensory information relayed through thalamocortical cells. During wakefulness, fast, short-duration IPSPs, ideal for maintaining high signal resolution, dominate, whereas in slow-wave sleep, slow, long-duration IPSPs, perfect for promoting oscillation and burst activity, prevail in the thalamus (Steriade et al., 1996).

Neuromodulators [e.g., acetylcholine (ACh)], which are released in a state-dependent manner, regulate the firing patterns in thalamic cells (Steriade et al., 1997). Activation of the cholinergic input from the brainstem, which occurs during arousal, affects sensory transmission in the thalamus (Sillito et al., 1983; Francesconi et al., 1988; Hartveit et al., 1993; Hartveit and Heggelund, 1994, 1995; Uhlrich et al., 1995). In particular, inhib-

\footnotetext{
Received Sept. 21, 2000; revised Dec. 1, 2000; accepted Dec. 7, 2000.

This work was supported by National Institutes of Health (R.M.), the Max-Planck Society, the Alexander von Humboldt Foundation, the NARSAD Foundation, and the Norwegian Research Council. J.J.Z. is the Naples Investigator of the NARSAD Foundation. We thank Drs. Bert Sakmann and Roberto Malinow for their support, Drs. Josh Huang, Fu-Sun Lo, Marie-Claude Perreault, Ed Ruthazer, and Ken Seidenman for their helpful discussions and comments, and Dr. Yi Qin for excellent technical assistance.

Correspondence should be addressed to J. Julius Zhu, Cold Spring Harbor Laboratory, Jones 1 Bungtown Road, Cold Spring Harbor, NY 11724. E-mail: Zhuju@cshl.org.

Copyright (C) 2001 Society for Neuroscience $\quad 0270-6474 / 01 / 211148-12 \$ 15.00 / 0$
}

conductance and two depolarizing cation conductances. The decrease in input resistance appeared to electrotonically uncouple the distal dendrites of thalamic interneurons, which effectively changed the inhibition pattern in thalamocortical cells. These results suggest a novel cellular mechanism for the cholinergic transformation of long-range, slow dendrite- and axon-originated inhibition into short-range, fast dendriteoriginated inhibition in the thalamus observed in vivo. It is concluded that the electrotonic properties of the dendritic compartments of thalamic interneurons can be dynamically regulated by muscarinic activity.

Key words: rat; thalamus; interneurons; inhibition; cholinergic receptors; cortex itory sharpening of sensory information is dramatically altered during the activation (Ahlsén et al., 1984; Hu et al., 1989; Hartveit and Heggelund, 1993; Murphy et al., 1994). In vitro studies have shown that various neuromodulators change the membrane potential of reticular and thalamocortical cells (Steriade et al., 1997), which switches their firing patterns by inactivating or deinactivating a low-threshold calcium current crucial for burst firing (Huguenard, 1996). This affects the sensory signals transmitted through the thalamus, because the forms of inhibition produced by reticular cells onto thalamocortical cells depend on the firing pattern of reticular cells (Huguenard and Prince, 1994; Destexhe and Sejnowski, 1995; Kim et al., 1997).

Compared with reticular cells, local interneurons appear to play a more important role in sharpening sensory information in the thalamus because they can produce larger varieties of inhibition on thalamocortical cells. These cells release GABA not only through conventional axonal terminals but also via the dendritic triadic structures, which are postsynaptic to the sensory afferents but presynaptic to the dendrites of thalamocortical cells and other interneurons (Ralston, 1971; Zhu and Lo, 1999; Cox and Sherman, 2000). The two release sites allow interneurons to generate multiple forms of inhibition in thalamocortical cells (Paré et al., 1991; Curró Dossi et al., 1992). In addition, interneurons have two or three prolonged dendrites and one locally branched axon (Zhu and Lo, 1999), which may contribute to the long- and short-range inhibitions observed in the thalamus in vivo (Eysel et al., 1986). How the distinct types of interneuron-mediated inhibition are differentially regulated, particularly during different behavioral states, is largely unknown. We examined muscarinic effects on the firing patterns (i.e., bursting vs tonic) (Zhu et al., 1999a) and outputs of interneurons. We found that the predom- 


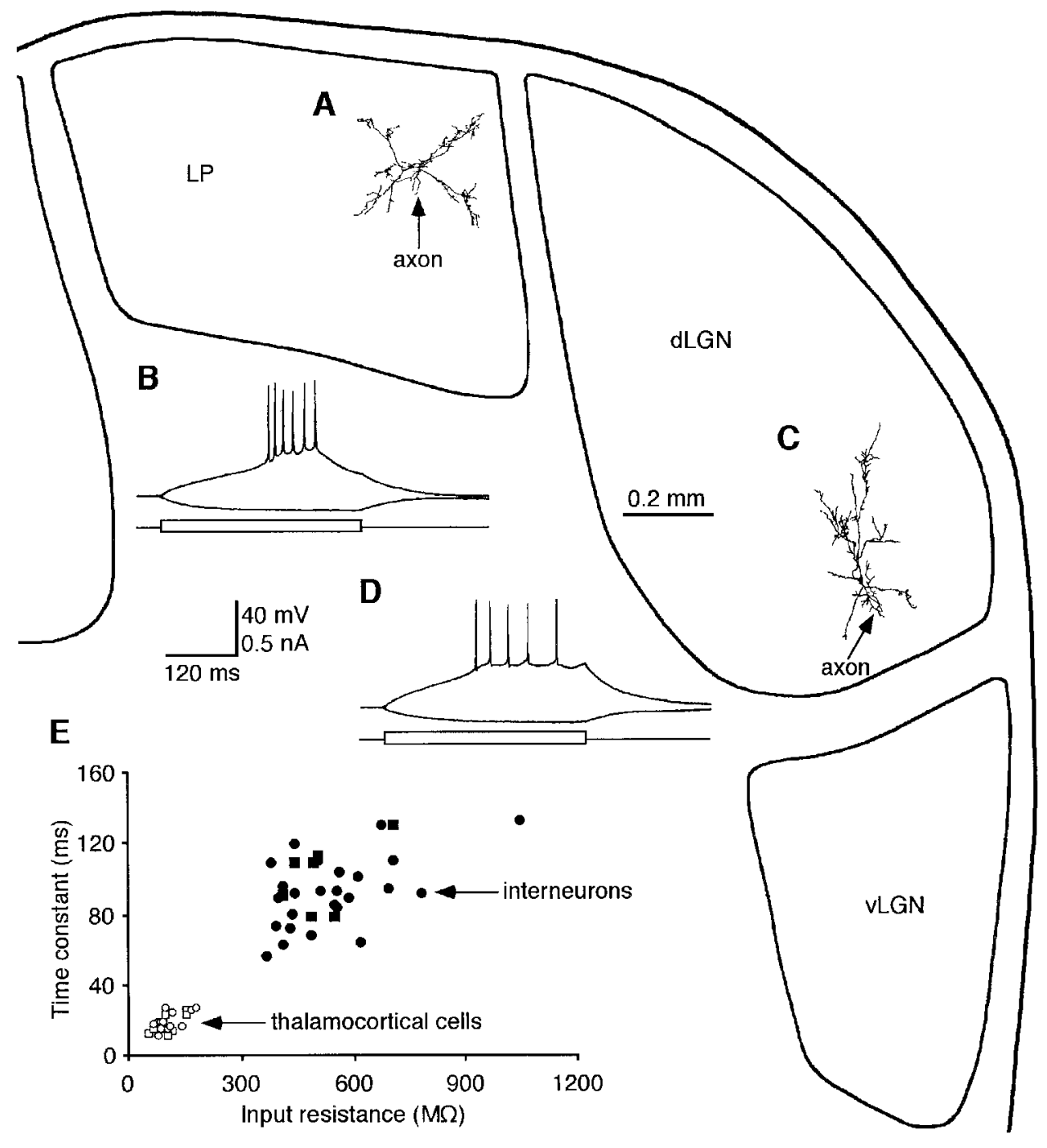

Figure 1. Thalamic interneurons. $A, C$, Morphology of reconstructed thalamic interneurons in the lateral posterior nucleus $(L P)$ and the dorsal lateral geniculate nucleus $(d L G N)$. Note that these cells were obtained from different slices. $B, D$, Responses of these interneurons to depolarizing and hyperpolarizing current pulses. $E$, Plot of the time constants of morphologically identified interneurons ( filled circles and filled squares for interneurons in LGN and LPN, respectively) and thalamocortical cells (open circles and open squares for thalamocortical cells in LGN and LPN, respectively) against their input resistances. No difference was found in the time constant $(\tau)$ or input resistance $\left(R_{\mathrm{i}}\right)$ among interneurons $(L P: 100.6 \pm 7.2 \mathrm{msec}, n=7$; $L G N: 92.0 \pm 3.8 \mathrm{msec}, n=27 ; t$ test, $p=$ 0.31 for $\tau ; L P N: 518 \pm 37 \mathrm{M} \Omega, n=7 ; L G N$ : $539 \pm 29 \mathrm{M} \Omega, n=27 ; t$ test, $p=0.72$ for $\left.R_{\mathrm{i}}\right)$ or among thalamocortical cells ( $L P N$ : $16.6 \pm 1.3 \mathrm{msec}, n=12 ; L G N: 17.9 \pm 1.2$ msec, $n=18 ; t$ test, $p=0.45$ for $\tau ; L P N$ : $98 \pm 9 \mathrm{M} \Omega, n=12 ; L G N: 102 \pm 8 \mathrm{M} \Omega, n=$ $18 ; t$ test, $p=0.77$ for $R_{\mathrm{i}}$ ) in $L P N$ and $L G N$. inate muscarinic effect was a decrease in input resistance in interneurons, which effectively switched the interneuron-mediated inhibition from a long-range, slow one to a local, fast one.

\section{MATERIALS AND METHODS}

Experiments were performed in thalamic slices from Wistar rats that were postnatal $27-56 \mathrm{~d}$ old (100-280 gm). No differences in electrophysiological properties of interneurons was found over this age range (Zhu et al., 1999c). The rats were deeply anesthetized by halothane and decapitated. The brain was then quickly removed and placed into cold $\left(1-4^{\circ} \mathrm{C}\right)$ physiological solution containing (in $\mathrm{mm}$ ): $\mathrm{NaCl} 125, \mathrm{KCl} 2.5$, $\mathrm{NaH}_{2} \mathrm{PO}_{4} 1.25, \mathrm{NaHCO}_{3} 25, \mathrm{MgCl}_{2}$, dextrose $25, \mathrm{CaCl}_{2}$ 2, at $\mathrm{pH}$ 7.4. This surgical operation, which appeared to be crucial for obtaining healthy slice tissues from the adult animals, was accomplished as fast as possible (within $15 \mathrm{sec}$ ). Slices containing lateral geniculate nucleus (LGN), each 300-500 $\mu \mathrm{m}$ thick, were then cut from the tissue blocks in cold $\left(0-4^{\circ} \mathrm{C}\right)$, oxygenated physiological solution, using a microslicer (Campden Instrument). The advance speed of the microslicer was adjusted to be as slow as possible during the slicing. These slices were then kept in warm $\left(37.0 \pm 0.5^{\circ} \mathrm{C}\right)$, oxygenated physiological solution for $\sim 1 \mathrm{hr}$ before recording. During the recordings, slices were submerged in a Plexiglas chamber and stabilized using a fine nylon net attached to a platinum ring. The chamber was perfused with warmed, oxygenated physiological solution, and the half-time for the bath solution exchange was $\sim 6 \mathrm{sec}$. The temperature of the bath solution in the chamber was kept at $35.0 \pm 0.5^{\circ} \mathrm{C}$. Agonists and antagonists were typically applied with the bath solution at $7-15$ min intervals. To examine the sustained muscarinic effects, $1 \mathrm{~mm}$ acetyl- $\beta$-methcholine (Mch) was continuously perfused with the physiological solution. Intrinsic and synaptic properties were studied typically $2-4$ min after the beginning of perfusion to ensure that the activation of muscarinic receptors reached the steady state. Brief $(4-8 \mathrm{sec})$ application of Mch was achieved by switching between two perfusing tubings containing either nothing or $1 \mathrm{mM} \mathrm{Mch} \mathrm{in}$ the physiological solution. Approximately 4-7 min were allowed to wash in and wash out the antagonists. TTX $(4 \mu \mathrm{M})$ was typically included in the bath solution after interneurons or thalamocortical cells were physiologically identified, except when the firing patterns or synaptic responses were examined.

Whole-cell recordings from thalamic interneurons and thalamocortical cells were made as described previously (Zhu and Lo, 1999). Patch electrodes were made from borosilicate tubing, and their resistances were 5-9 $\mathrm{M} \Omega$ with our intracellular solution containing (in $\mathrm{mM}$ ): potassium gluconate 115 , HEPES $10, \operatorname{MgATP} 2, \mathrm{Na}_{2}$ ATP 2, GTP 0.3 , and $\mathrm{KCl} 20$ at $\mathrm{pH}$ 7.3. Liquid junction potential $(9 \mathrm{mV})$ was subtracted from all membrane potentials. We found little washout effect on the intracellular $\mathrm{Ca}^{2+}$ concentration with this intracellular solution, as indicated by no change in $\mathrm{Ca}^{2+}$-dependent muscarinic depolarization during the prolonged recordings (see Fig. 3C,D) (cf. Helmchen et al., 1996). Whole-cell recordings were made with up to two Axoclamp-2B or Axopatch-1D amplifiers (Axon Instruments). Single-electrode voltage-clamp mode was chosen to record current responses. To obtain current versus voltage $(I-V)$ plots, the cells were initially held at -70 $\mathrm{mV}$. Then, after $2 \mathrm{sec}$ of hyperpolarization of -130 to $-125 \mathrm{mV}$, the 

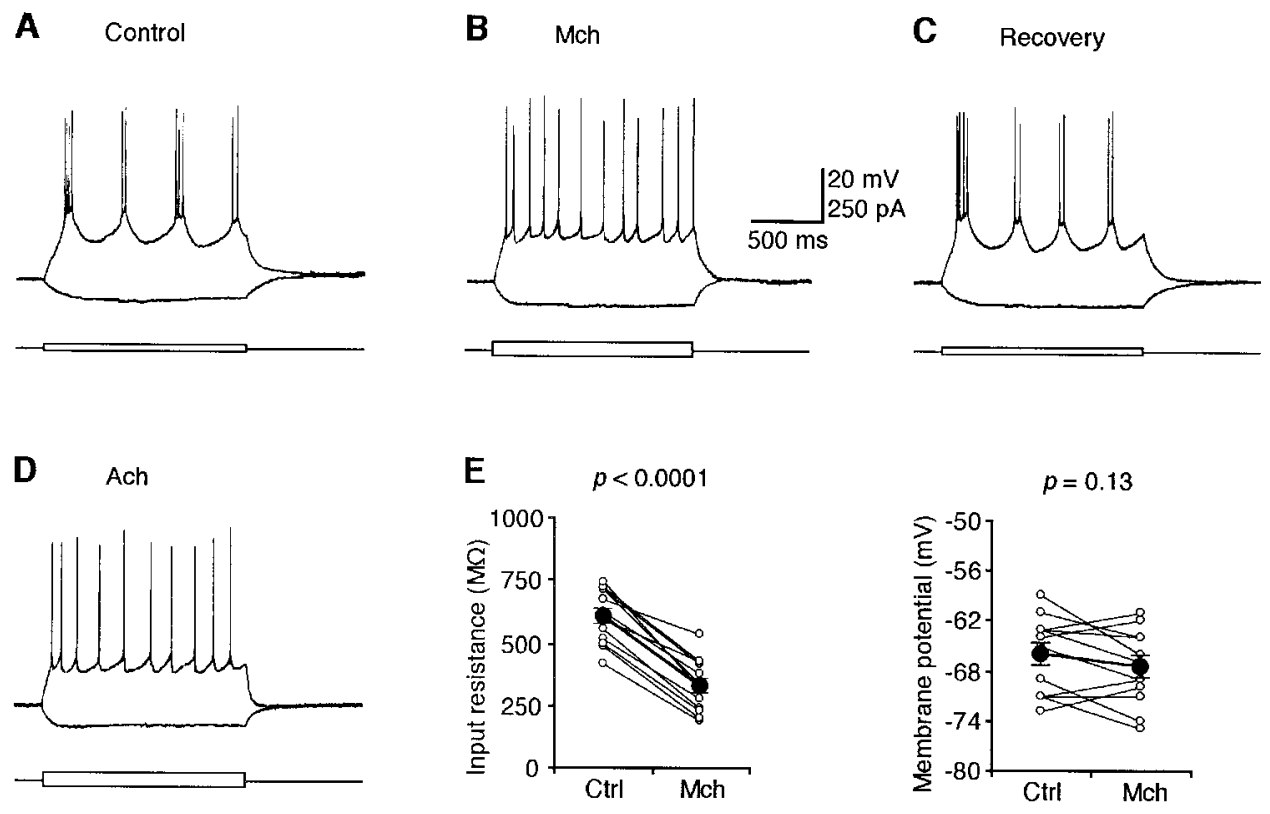

Figure 2. Responses of rat thalamic interneurons to bath application of Mch. $A$, Responses of a thalamic interneuron to depolarizing and hyperpolarizing current pulses. $B-D$, Bath application of $1 \mathrm{~mm} \operatorname{Mch}(n=$ $22)$ or $0.5 \mathrm{~mm} \mathrm{ACh}(n=5)$ decreased the input resistance of the cell and switched its burst firing pattern to a tonic firing one. Note the reduction of action potential number in the initial burst after application of Mch (Control: $5.2 \pm 0.6 ;$ Mch: $1.8 \pm 0.3 ; n=$ $9 ; p<0.0001)$ and large current needed to evoked action potentials during application of agonists. The responses were reversible (not shown for ACh application). E, Input resistance (Ctrl: $602 \pm 32 \mathrm{M} \Omega$; Mch: $328 \pm$ $31 \mathrm{M} \Omega ; n=12 ; p<0.0001)$ and resting membrane potential $(\mathrm{Ctrl}:-66.1 \pm 1.3 \mathrm{mV}$; $M c h:-67.7 \pm 1.3 \mathrm{mV} ; n=12 ; p=0.13)$ of thalamic interneurons in control or with Mch in bath solution. Large filled circles represent average values (same in the following figures). $F$, Dose-dependence interneuron responses to bath solution of Mch (left, $n=4$ ) and ACh (right, $n=3$ ). Note the monotonically increasing effect on the input resistance but not on the resting potential. Sigmoid curves in $F$ are the best fitting curves for the average data points from Mch $(p \mathrm{Ki}=4.50, n \mathrm{H}=0.48)$ and $\mathrm{ACh}(p \mathrm{Ki}=4.02, n \mathrm{H}=0.45)$ responses.
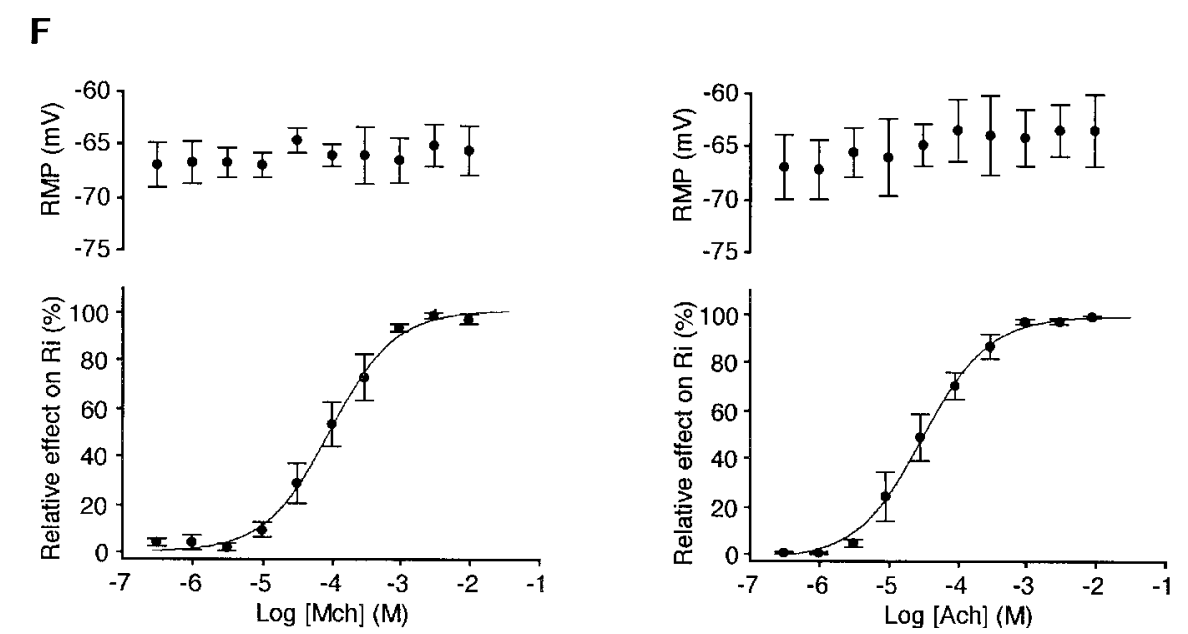

membrane potential was continuously ramped to -55 to $-40 \mathrm{mV}$ over a period of $5-10 \mathrm{sec}$.

Synaptic responses were examined using both acute and organotypic culture thalamic slices. Only slices that contain no thalamic reticularnucleus were used (sliced from bregma -5.0 to -4.2 ). As described previously (Zhu et al., 2000), culture slices were incubated in the culture medium containing (in percentage or $\mathrm{mM}$ ): MEM 79\%, horse serum $20 \%$, L-glutamine 3, glucose $18.4, \mathrm{NaHCO}_{3} 5, \mathrm{CaCl}_{2} 2.26, \mathrm{MgSO}_{4} 2.81$, HEPES 30, ascorbic acid 0.07, insulin 0.00017, at pH 7.28. Cortical slices from the same animals were co-cultured with the thalamic explants to increase the survival rate of thalamic cells (cf. Bolz et al., 1992; Sieg et al., 1998). The recordings were performed at $\sim 36-72 \mathrm{hr}$ after culture, which allowed only degeneration of the severed axons from reticular cells (Ohara et al., 1980) but not large-scale reorganization of the local circuitry (cf. McKinney et al., 1999). The survived thalamic interneurons and thalamocortical cells from culture slices appeared to be healthy, and they had the same resting membrane potential (acute: $-66.5 \pm 0.8 \mathrm{mV}$, $n=34$; culture: $-62.5 \pm 1.8 \mathrm{mV}, n=4 ; t$ test, $p=0.12$ for interneurons; acute: $-68.3 \pm 0.7 \mathrm{mV}, n=30$; culture: $-66.4 \pm 0.9 \mathrm{mV}$, $n=17 ; t$ test, $p=0.14$ for thalamocortical cells), input resistance (acute: $535 \pm 24 \mathrm{M} \Omega, n=34$; culture: $578 \pm 50 \mathrm{M} \Omega, n=4$; $t$ test, $p=$ 0.56 for interneurons; acute: $98 \pm 6 \mathrm{M} \Omega, n=30$; culture: $108 \pm 9 \mathrm{M} \Omega$, $n=17 ; t$ test, $p=0.49$ for thalamocortical cells), and time constant (acute: $93.8 \pm 3.3 \mathrm{msec}, n=34$; culture: $92.0 \pm 3.8 \mathrm{msec}, n=4 ; t$ test, $p=0.35$ for interneurons; acute: $17.1 \pm 0.8 \mathrm{msec}, n=30$; culture: $15.1 \pm 0.8 \mathrm{msec}, n=17$; $t$ test, $p=0.09$ for thalamocortical cells) as those recorded from acute slices. Thalamic interneurons were directly activated by one or two bipolar electrodes (FHC Inc., Bowdoinham, $\mathrm{ME})$ with single voltage pulses $(200 \mu \mathrm{sec}, 0.4-7 \mathrm{~V}, 0.25 \mathrm{~Hz})$. NBQX (5 $\mu \mathrm{M})$ and DL-AP5 $(100 \mu \mathrm{M})$ were included in the bath solution to block excitatory synaptic transmission. Stimulating electrodes were placed $\sim 200 \mu \mathrm{m}$ away from the recorded interneurons and $\sim 200-500 \mu \mathrm{m}$ away from the recorded thalamocortical cells to induce direct excitation in interneurons, proximal and/or distal interneuron-mediated inhibitions in thalamocortical cells. The similar stimulation intensity was used for activating the proximal and distal populations of interneurons. Synaptic responses were averaged over 10-50 trials. All results are reported as mean \pm SEM. Statistical differences of the means were determined using paired $t$ test unless stated otherwise. The level of significance was set at $p<0.05$.

To recover cell morphology, biocytin $(0.25 \%)$ was included in the intracellular solution. After recordings, slices were fixed by immersion in $0.1 \mathrm{M}$ phosphate buffer containing $4 \%$ paraformaldehyde, resected into 150 - to $250-\mu \mathrm{m}$-thick sections, and histologically reacted for biocytin to recover the cell morphology. Cells were subsequently drawn under $100 \times$ objective with the aid of a computerized reconstruction system (Neurolucida 3.18) or a camera lucida system. Chemicals were purchased from Sigma-RBI (St. Louis, MO). 
A
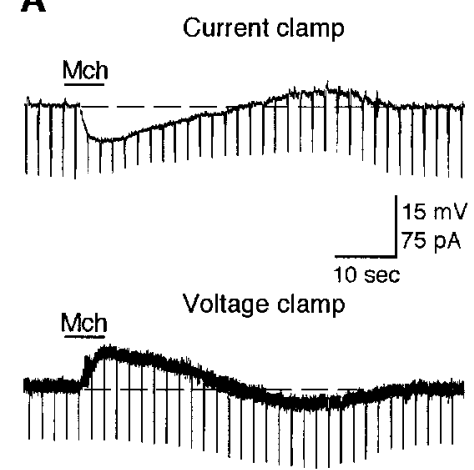

C
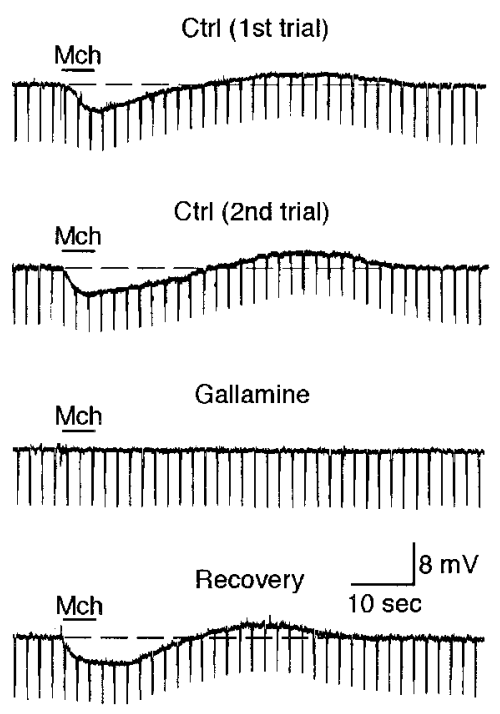

B

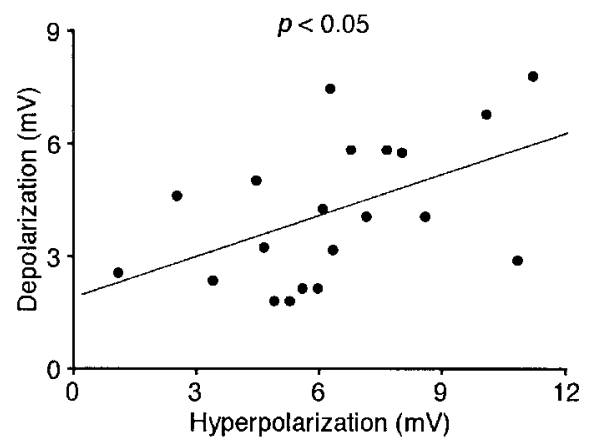

D
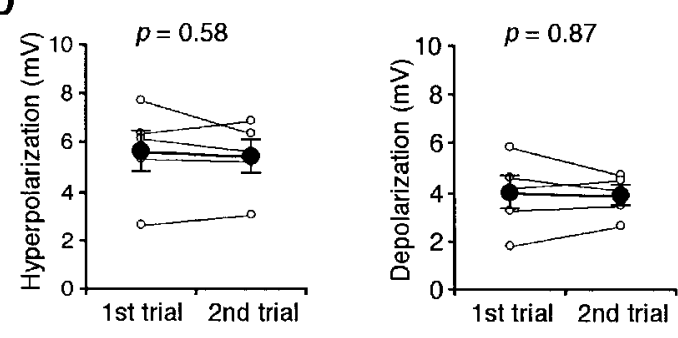

E

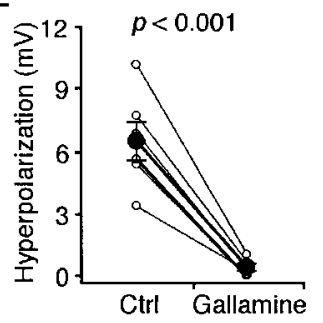

Figure 3. Involvement of muscarinic subtype 2 receptors in Mch-evoked responses in thalamic interneurons. $A$, Brief bath application of $1 \mathrm{~mm} \mathrm{Mch}(4-8 \mathrm{sec})$ induced a hyperpolarization followed by a depolarization in current-clamp mode or an outward current followed by an inward current in voltage-clamp mode. Note that both hyperpolarization and depolarization were accompanied by a decrease in input resistance (Ctrl: $542 \pm 35 \mathrm{M} \Omega ;$ Hyperpolarization: $397 \pm 27 \mathrm{M} \Omega ; p<0.0001 ; n=21 ;$ Depolarization: $435 \pm 27 \mathrm{M} \Omega ; n=21 ; p<$ $0.0001)$. $B$, Plot of peak amplitudes of depolarization $(4.2 \pm 0.4 \mathrm{mV})$ against that of hyperpolarization $(-6.4 \pm 0.6 \mathrm{mV})$ induced by brief application of $\operatorname{Mch}(r=0.51$; $n=21$; ANOVA, $p<0.05)$. Linear line is a regression line. $C$, The muscarinic responses exhibited little desensitization to successive brief applications of $1 \mathrm{~mm}$ Mch but were blocked by bath application of 200 nM gallamine. $D$, Hyperpolarization $(\mathrm{Ctrl}$ : $5.6 \pm 0.8 \mathrm{mV} ;$ Mch: $5.4 \pm 0.7 \mathrm{mV} ; n=5$; $p=0.58)$ and depolarization (Ctrl: $3.9 \pm 0.7$ $\mathrm{mV} ;$ Mch: $3.9 \pm 0.4 \mathrm{mV} ; n=5 ; p=0.87)$ evoked by the first and second applications of Mch. E. Hyperpolarization (Ctrl: $6.5 \pm$ $0.9 \mathrm{mV} ;$ Mch: $0.3 \pm 0.2 \mathrm{mV} ; n=6 ; p<$ $0.001)$ and depolarization (Ctrl: $4.1 \pm 0.9$ $\mathrm{mV} ;$ Mch: $0.2 \pm 0.1 \mathrm{mV} ; n=6 ; p<0.01)$ in control and with gallamine in bath solution.

\section{RESULTS}

\section{Identification of GABAergic interneurons in the thalamus}

We studied muscarinic effects on interneurons and interneuronmediated inhibition in thalamocortical cells in the lateral posterior nucleus (LPN) and LGN of the rat's thalamus using the whole-cell recording technique (Fig. 1). Once the whole-cell configuration was formed, thalamic interneurons could be unambiguously distinguished from thalamocortical cells by their distinct physiological properties, such as high input resistance and long membrane time constant (Fig. 1B,D) (Pape et al., 1994; Williams et al., 1996; Zhu and Uhlrich, 1997; Zhu et al., 1999a). Both interneurons and thalamocortical cells could generate bursts of action potentials. However, the intraburst firing frequency in interneurons $(<150 \mathrm{~Hz})$ was lower than that in thalamocortical cells $(>250 \mathrm{~Hz})$ (cf. Deschênes et al., 1984; Williams et al., 1996; Zhu and Lo, 1998, 1999; Zhu et al., 1999d). The morphology of 34 interneurons and 30 thalamocortical cells was recovered (Fig. $1 A, C)$. Interneurons in LPN and LGN had the distinguishing dendritic and axonal branching pattern as described previously (Williams et al., 1996; Zhu and Uhlrich, 1997; Zhu and Lo, 1999), characteristic for GABAergic interneurons in the thalamus (Ohara et al., 1983; Ottersen and Storm-Mathisen, 1984; Webster and Rowe, 1984; Gabbott et al., 1986). Interneurons recorded from LPN and LGN showed no difference in input resistance and time constant (Fig. 1E). However, these two properties were
A

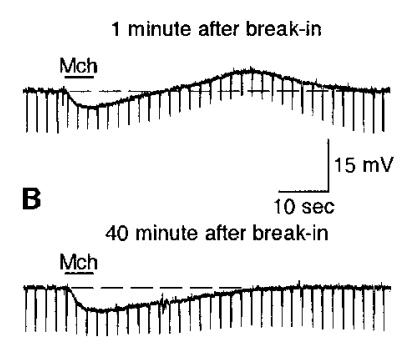

C

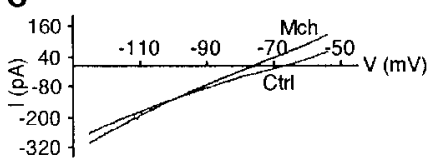

D

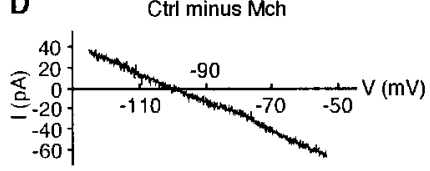

Figure 4. Muscarinic activity enhances a potassium conductance in thalamic interneurons. $A$, Brief bath application of $1 \mathrm{~mm}$ Mch induced a hyperpolarization followed by a depolarization right after the formation of the wholecell configuration. $B$, Depolarization was blocked after intracellular loading of $5 \mathrm{~mm}$ EGTA for $20-50 \mathrm{~min}(n=4)$. $C, I-V$ relationships obtained before $(\mathrm{Ctrl})$ and after application of Mch. Note that current versus voltage $(I-V)$ plots were obtained by ramping membrane potential from -130 or -125 to -55 or $-40 \mathrm{mV}$ over a period of 5-10 sec. $D$, Difference between control $I-V$ relation and that obtained $5 \mathrm{sec}$ after application of Mch reveals that Mch affected a relatively linear current that reversed at $-100.5 \pm 1.2 \mathrm{mV}(n=6)$.

sufficient to distinguish interneurons from thalamocortical cells; the distributions of input resistance and time constant from interneurons did not overlap with those from thalamocortical cells (Fig. 1E). 
A

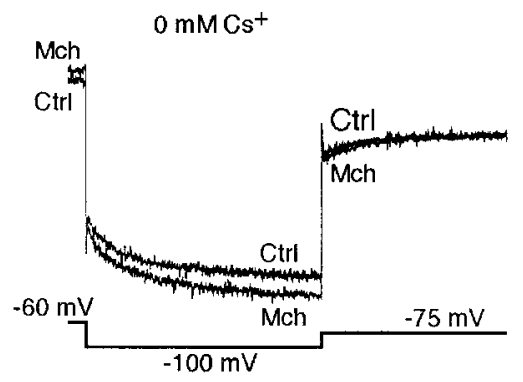

C

Figure 5. Muscarinic activity enhances two cation conductances in thalamic interneurons. $A, C$, Stepping voltage to -100 $\mathrm{mV}$ before $(\mathrm{Ctrl})$ and $20 \mathrm{sec}$ after application of $1 \mathrm{~mm}$ Mch in two interneurons revealed that the slowly activated inward current was augmented during the muscarinic response. The effect was blocked by bath application of $2 \mathrm{mM} \mathrm{Cs}^{+}(B ; n=7)$ or intracellular loading of $5 \mathrm{~mm}$ EGTA $(D$; $n=3)$. Note that the muscarinic activity generated a net outward current when cells were held at a depolarized membrane potential $(-0 \mathrm{mV})$, where $I_{\mathrm{b}}$ was largely inactivated (Zhu et al., 1999b). Calibration in $D$ applies also to $A-C$. $E, I-V$ relationships obtained from another interneuron before (Ctrl) and 35-45 sec after application of Mch, whereas $2 \mathrm{~mm} \mathrm{Cs}^{+}$was included in the bath solution. Inset, Subtracting the control $I-V$ relation from that obtained after application of Mch reveals that Mch induced a linear inward current that reversed at $4.5 \pm 3.9 \mathrm{mV}(n=4) . F$, Substituting extracellular $\mathrm{Na}^{+}$ions with $\mathrm{NMDG}^{+}$ions blocked the effect $(n=3)$.
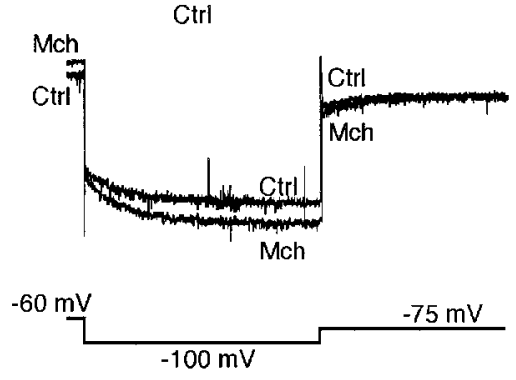

B
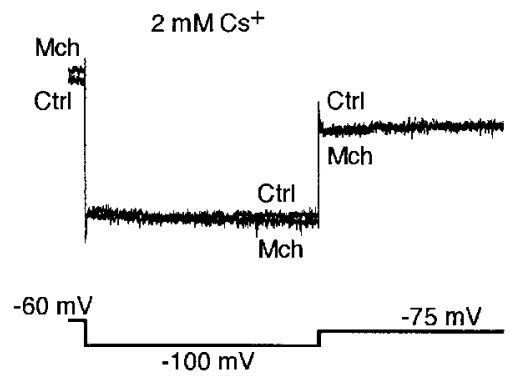

D

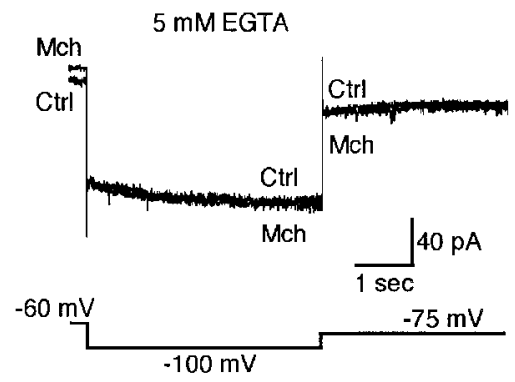

$\mathbf{F}$

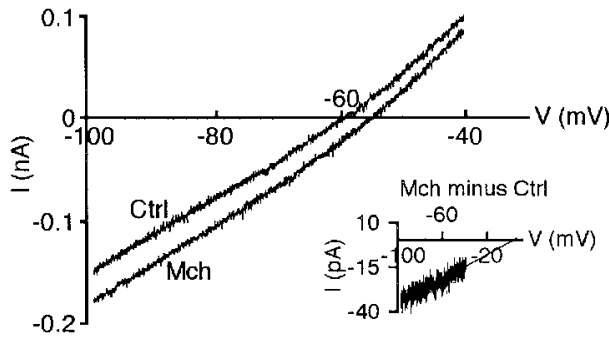

\section{Effects of muscarinic activity on firing mode in thalamic interneurons}

We have shown previously that adult thalamic interneurons can generate burst firing and oscillation (Zhu et al., 1999a). The same burst firing and oscillation were observed in this study (Fig. 2) $(n=51)$. A previous in vivo study has shown that thalamusprojecting, cholinergic cells in the brainstem fire tonic action potentials, and their firing rate increases during wakefulness (Steriade et al., 1990). To test whether a sustained increase of muscarinic receptor activity could modify the burst firing pattern of interneurons, we continuously applied $1 \mathrm{~mm}$ Mch, a muscarinic agonist (McCormick 1992a; Zhu and Uhlrich, 1998), through the bath solution. The application of Mch reversibly suppressed burst firing and bursting oscillation in thalamic interneurons (Fig. $2 B, C)$. Similar effects were found by bath application of ACh (Fig. $2 D$ ), although ACh also induced a brief, quickly desensitizing depolarization resulting from the activation of nicotinic receptors (Zhu and Uhlrich, 1997).

Bath application of Mch also had a prominent effect on input resistance of interneurons, but not on resting membrane potential measured when muscarinic activity reached to steady state (Fig. $2 E$ ). Using the change of input resistance as an indicator, we measured the dose-response curve of both Mch and ACh (Fig. $2 F)$. Mch and ACh began to show evident effect at $\sim 10 \mu \mathrm{M}$ concentration, and $1 \mathrm{~mm}$ Mch and $0.5 \mathrm{~mm}$ ACh activated most of the muscarinic receptors $(\sim 95 \%)$ in interneurons. No change in resting membrane potential was observed at different concentrations of the agonists.

\section{Muscarinic receptor-evoked responses in thalamic interneurons}

A brief application of Mch to the recording chamber was used to dissect the Mch-evoked responses in interneurons (Fig. $3 A)(n=$ 21). Interneurons responded to the brief Mch application with a hyperpolarization, which had a latency of $\sim 1-3 \mathrm{sec}$ and a duration of $\sim 16-28 \mathrm{sec}$. The hyperpolarization was followed by a depolarization, which had a latency of $\sim 16-28 \mathrm{sec}$ and a duration of $\sim 20-35 \mathrm{sec}$. The amplitudes of the hyperpolarization correlated with those of the depolarization (Fig. 3B). This result suggests that if Mch induces a large hyperpolarization in an interneuron, it will also induce a large depolarization in the same cell. The muscarinic receptors exhibited little desensitization because successive applications of Mch showed little change in the amplitude of hyperpolarization or depolarization (Fig. 3C,D). We also tested the effect of bath application of $1 \mathrm{~mm}$ Mch on some of these cells. Bath application of Mch induced the expected decrease in input resistance (Ctrl: $611 \pm 51 \mathrm{M} \Omega$; Mch: $332 \pm 40$ 
A
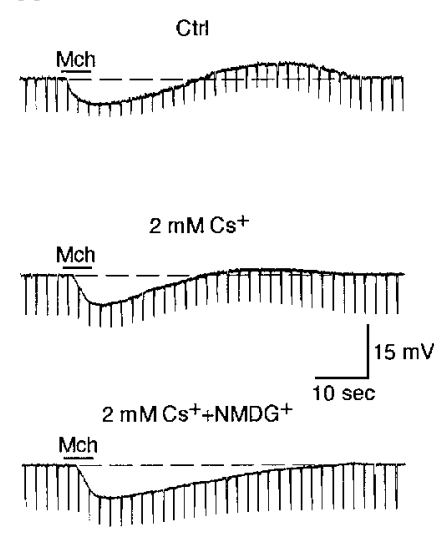

B
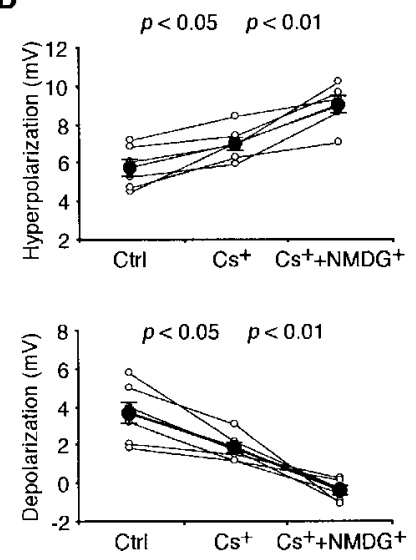

Figure 6. Two cation conductances mediate muscarinic depolarization in thalamic interneurons. $A$, Muscarinic depolarization induced by brief application of $1 \mathrm{~mm}$ Mch was partially blocked by bath application of $2 \mathrm{~mm}$ $\mathrm{Cs}^{+}$and completely blocked by further substituting extracellular $\mathrm{Na}^{+}$ ions with $\mathrm{NMDG}^{+}$ions. Note that these channel blockers increased the input resistance of the cell. $B$, Hyperpolarization $(C t r l: 5.8 \pm 0.4 \mathrm{mV}$; $C s^{+}: 7.0 \pm 0.3 \mathrm{mV} ; p<0.05 ; n=6 ; C s^{+}+N M D G^{+}: 9.0 \pm 0.4 \mathrm{mV} ; n=$ $6 ; p<0.01)$ and depolarization $\left(C t r l: 3.7 \pm 0.6 \mathrm{mV} ; \mathrm{Cs}^{+}: 1.8 \pm 0.3 \mathrm{mV}\right.$; $\left.p<0.05 ; n=6 ; \mathrm{Cs}^{+}+N M D G^{+}:-0.4 \pm 0.2 \mathrm{mV} ; n=6 ; p<0.01\right)$ in control and with one or two channel blockers.

$\mathrm{M} \Omega ; n=5 ; p<0.005)$ with little change in membrane potential (Ctrl: $-64.0 \pm 1.9 \mathrm{mV} ;$ Mch: $-64.8 \pm 1.8 \mathrm{mV} ; n=5 ; p=0.65)$.

Recent studies have shown that muscarinic subtype 2 (M2) receptors are highly expressed in the dendrite and soma of thalamic interneurons (Carden and Bickford, 1999; Plummer et al., 1999). We tested whether Mch-evoked responses in interneurons were mediated by M2 receptors. Bath application of $200 \mathrm{nM}$ gallamine, a selective M2 receptor antagonist (Michel et al., 1990), reversibly blocked the muscarinic hyperpolarization and depolarization (Fig. 3C,E), indicating that the Mch-evoked responses were mediated mainly by $\mathrm{M} 2$ receptors.

\section{Cellular mechanisms underlying the muscarinic responses in thalamic interneurons}

An early study has shown that activation of M2 muscarinic receptors induces a delayed $\mathrm{Ca}^{2+}$ release from intracellular stores (Lechleiter et al., 1991). To test whether the muscarinic responses were mediated by increased concentration of intracellular $\mathrm{Ca}^{2+}$, we included 5 mM EGTA in the intracellular solution. We found that the depolarizing response to a brief application of Mch was blocked after loading EGTA for $\sim 30 \mathrm{~min}$, whereas the hyperpolarizing response changed little (Fig. 4A,B). Consistent with the EGTA blockade of intracellular $\mathrm{Ca}^{2+}$ increase, we found that continuous perfusion of $1 \mathrm{~mm}$ Mch with the bath solution resulted in a sustained hyperpolarization in membrane potential in cells loaded with EGTA $(n=2)$ (data not shown). No change in hyperpolarization and depolarization to a brief application of Mch was found in cells recorded with normal intracellular solution (Fig. 3C,D). These results suggest that the depolarizing response is mediated by muscarinic receptor-stimulated increase of intracellular $\mathrm{Ca}^{2+}$ in interneurons.

Taking advantage of the isolated hyperpolarization, we studied its cellular mechanism using the single-electrode voltage-clamp technique. To do that, we obtained current versus voltage plots by

ramping the voltage from $-130 \mathrm{mV}$ to $-55 \mathrm{mV}$ and measuring the current required to achieve the voltage. Current versus voltage plots of control and $5 \mathrm{sec}$ after application of Mch were obtained in this way (Fig. 4C). The difference of current versus voltage plots revealed that Mch induced an outward current that reversed at approximately $-100 \mathrm{mV}$, the expected potassium reversal potential $(n=3)$ (Fig. $4 D)$. The outward current had a relatively linear $I-V$ relationship. The same result was obtained from three other cells without loading EGTA. These results indicate that an enhancement of a potassium conductance underlies the Mch-evoked early hyperpolarization.

Because a hyperpolarization-activated cation current $\left(I_{\mathrm{h}}\right)$ is present in thalamic interneurons (Zhu et al., 1999b) and this current is enhanced when the intracellular $\mathrm{Ca}^{2+}$ concentration is raised (Hagiwara and Irisawa, 1989; Zhu and Uhlrich, 1998; Luthi and McCormick, 1999), we tested whether the Mch-evoked depolarization was mediated by $I_{\mathrm{h}}$. The effect of Mch on $I_{\mathrm{h}}$ was examined by comparing the currents induced by stepping the command voltage from -60 to $-100 \mathrm{mV}$ at control and $20 \mathrm{sec}$ after a brief application of Mch (Fig. 5A,C). This target voltage was chosen for two reasons. First, it elicits a near-maximal activation $I_{\mathrm{h}}$. Second, it is near the reversal potential of the potassium current, thereby minimizing contamination from the muscarinic effects on the potassium current. In all seven cells tested, the slowly activated inward current, $I_{\mathrm{h}}$, was increased after application of Mch, suggesting that $I_{\mathrm{h}}$ was upregulated by Mch. Bath application of $2 \mathrm{mM} \mathrm{Cs}^{+}$(Fig. $5 B$ ), which blocks $I_{\mathrm{h}}$, or intracellular loading of 5 mм EGTA (Fig. 5D), which suppresses the $\mathrm{Ca}^{2+}$-dependent modulation on $I_{\mathrm{h}}$, abolished the effect, confirming that muscarinic activity upregulated $I_{\mathrm{h}}$ in interneurons.

Bath application of $\mathrm{Cs}^{+}$also revealed a small Mch-evoked, sustained inward current when interneurons were held at -100 $\mathrm{mV}$ (Fig. 5B). We suspected that this current was mediated by a $\mathrm{Ca}^{2+}$-activated cation conductance $\left(I_{\mathrm{CAN}}\right)$, which also exists in thalamic interneurons (Zhu et al., 1999d). Given the small amplitude of the inward current, we chose only cells with large muscarinic depolarization to test whether Mch activated $I_{\mathrm{CAN}}$. Current versus voltage plots, with voltage ramped from $-100 \mathrm{mV}$ to $-40 \mathrm{mV}$, were obtained at control condition and $\sim 40 \mathrm{sec}$ after application of Mch to minimize contamination from the muscarinic effect on the hyperpolarizing conductance (Figs. 4B, 6A). With $2 \mathrm{~mm} \mathrm{Cs}^{+}$also included in the bath solution, the difference of the current plots revealed a relatively linear current activated by Mch (Fig. $5 E$ and inset). The average reversal potential suggests that a cation conductance, presumably $I_{\mathrm{CAN}}$, is activated by Mch. Substituting extracellular $\mathrm{Na}^{+}$ions with $\mathrm{NMDG}^{+}$ions, which blocked $I_{\text {CAN }}$, eliminated the effect (Fig. $5 F$ ), supporting the notion that the sustained inward current was mediated by $I_{\text {CAN }}$. Together, these results suggest that Mch-evoked depolarization in thalamic interneurons is mediated by the enhancement of both $I_{\mathrm{h}}$ and $I_{\mathrm{CAN}}$.

To further confirm that the enhancement of $I_{\mathrm{h}}$ and $I_{\mathrm{CAN}}$ mediates the muscarinic depolarization, we tested the effect of $\mathrm{Cs}^{+}$and $\mathrm{NMDG}^{+}$ions on the depolarization evoked by brief application of Mch (Fig. 6A). Bath application of $\mathrm{Cs}^{+}$ions and substitution of extracellular $\mathrm{Na}^{+}$ions with $\mathrm{NMDG}^{+}$ions increased the input resistance of interneurons, which results in increases in the hyperpolarizing response evoked by brief application of Mch (Fig. 6B). In contrast, the depolarizing response was partially blocked by $2 \mathrm{mM} \mathrm{Cs}^{+}$and completely blocked after substitution of extracellular $\mathrm{Na}^{+}$ions by $\mathrm{NMDG}^{+}$ions (Fig. $6 B$ ). 
Figure 7. Blockade of $\mathrm{GABA}_{\mathrm{B}}$ inhibition in thalamocortical cells by muscarinic activity. $A$, Schematic drawing of recording and stimulating electrodes indicates the location of the stimulating electrode, placed within the dendritic tree of the recorded interneuron $(\sim 200 \mu \mathrm{m}$ away from the soma). $B$, Direct electric shock evoked a large depolarization and a burst of action potentials in an interneuron in the presence of $5 \mu \mathrm{M}$ NBQX and $100 \mu \mathrm{M}$ DL-AP5. Bath application of $1 \mathrm{~mm}$ Mch transformed bursting firing into single action potential responses. $C$, Number of action potentials, averaged over 8-16 trials, in control or with Mch in bath solution (Ctrl: $2.8 \pm 0.4$; Mch: $0.8 \pm$ $0.1 ; n=5 ; p<0.01)$. Circles and squares represent data points obtained from acute and culture slices, respectively (same in $F$ and Fig. 8). D, Schematic drawing of recording and stimulating electrodes indicates the location of the stimulating electrode, placed $\sim 200-500 \mu \mathrm{m}$ away from the soma of the recorded thalamocortical cell. E, Direct electric shock evoked a prolonged IPSP in a thalamocortical cell in the presence of $5 \mu \mathrm{M}$ NBQX and $100 \mu \mathrm{M}$ DL-AP5. Bath application of $10 \mu \mathrm{M}$ PTX blocked the early component of the IPSP. The later component of the IPSP was blocked by $1 \mathrm{~mm}$ saclofen $(n=$ 3) or $1 \mathrm{~mm}$ Mch. $F$, Amplitude of later IPSPs in control or with Mch in bath solution (Ctrl: $0.51 \pm 0.09 \mathrm{mV}$; Mch: $0.03 \pm 0.01$ $\mathrm{mV} ; n=15 ; p<0.0001)$.

This is consistent with the hypothesis that $I_{\mathrm{h}}$ and $I_{\mathrm{CAN}}$ mediate the muscarinic depolarization.

Together these results indicate that muscarinic activity activates both depolarizing and hyperpolarizing conductances in interneurons, with little desensitization. This explains why the prolonged bath application of Mch results in a large decrease in input resistance but little net change in membrane potential after muscarinic activity reaches the steady state.

\section{Effects of muscarinic activity on interneuron-mediated inhibition in thalamocortical cells}

We wished to examine whether the muscarinic effects on interneurons can modulate the interneuron-mediated inhibition in thalamocortical cells. We added NBQX and DL-AP5 in the bath solution to block the excitatory synaptic transmission and then stimulated interneurons directly by placing the stimulating electrodes within LPN or LGN. Direct stimulation of interneurons in LPN $(n=1)$ and LGN $(n=4)$ evoked a large depolarization, which could lead to a burst of two to six action potentials (Fig. $7 A, B)$. Bath application of Mch suppressed the depolarization and transformed the bursts into a subthreshold response or single action potential response (Fig. $7 B, C$ ).

We then tested whether suppression of burst responses in interneurons by Mch can subsequently affect the inhibition in thalamocortical cells. Because of the long dendrites of interneurons in LPN and LGN, we could locally excite a population of interneurons without activating their postsynaptic thalamocortical cells directly (Fig. 7D,E). Recording from postsynaptic thalamocortical cells showed that such stimulation evoked a prolonged IPSP (Fig. 7E). The IPSP appeared to have two components. The early part of the response was blocked by bath application of picrotoxin (PTX), a $\mathrm{GABA}_{\mathrm{A}}$ receptor blocker, leaving
B

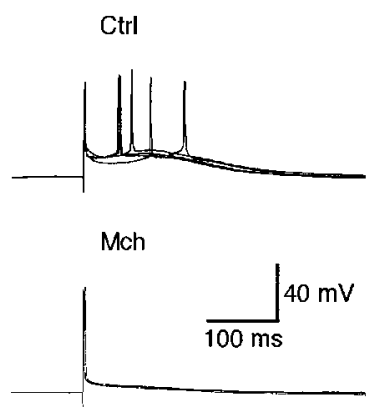

C

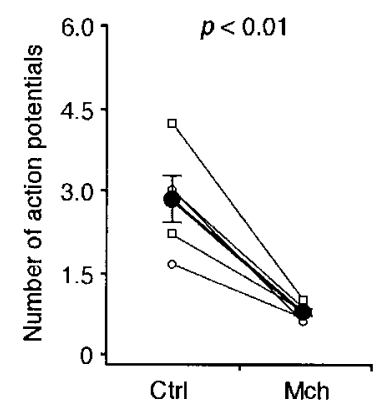

$\mathbf{E}$

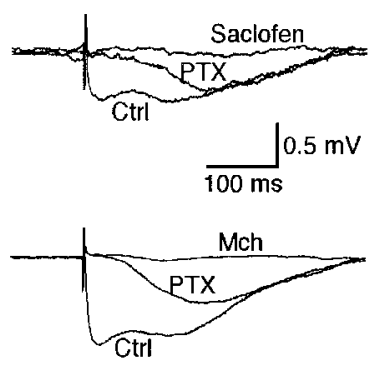

$\mathbf{F}$

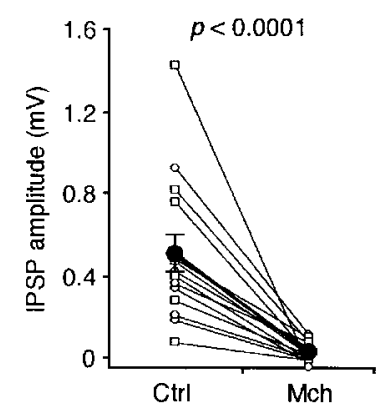

a small and slow IPSP. This slow IPSP was blocked by bath application of saclofen, a $\mathrm{GABA}_{\mathrm{B}}$ receptor blocker, or Mch (Fig. $7 E, F)$, although Mch also induced a depolarization and an increase in input resistance in thalamocortical cells [data not shown; but see Zhu and Uhlrich (1998)]. The same muscarinic effect on $\mathrm{GABA}_{\mathrm{B}}$ response was found in thalamocortical cells recorded from culture slices (Fig. $7 F$ ). Because the severed axons of reticular cells degenerate after $24 \mathrm{hr}$ (Ohara et al., 1980), the results suggest that the interneuron-mediated $\mathrm{GABA}_{\mathrm{B}}$ IPSP is largely blocked by muscarinic activity.

The muscarinic effect on interneuron-mediated $\mathrm{GABA}_{\mathrm{A}}$ IPSP was also studied. In this experiment, we directly stimulated two populations of interneurons (proximally located vs distally located) by placing two stimulating electrodes at $\sim 250$ and $\sim 500$ $\mu \mathrm{m}$ away from the recorded thalamocortical cells, respectively (Fig. 8A). Both distal and proximal stimulation could evoke a prolonged IPSP in thalamocortical cells, and the $\mathrm{GABA}_{\mathrm{A}^{-}}$ mediated response could be isolated by the bath application of saclofen (Fig. 8B). Although bath application of Mch had a significant suppression on the distal stimulation-evoked $\mathrm{GABA}_{\mathrm{A}}$ IPSP, it had much less effect on the proximal stimulation-evoked $\mathrm{GABA}_{\mathrm{A}}$ IPSP (Fig. $8 B-E$ ). In several cases, the latter IPSP was actually enhanced (Fig. $8 C$ ), presumably reflecting a muscarinic increase of input resistance and depolarization in postsynaptic thalamocortical cells (Zhu and Uhlrich, 1998). A similar result was obtained from the culture slices (Fig. $8 C-E$ ). Although Mch produced a slightly larger suppression on the distal inhibition in culture slices than in acute slices, the difference was not statistically significant (Fig. 8E), suggesting that the inhibition induced by the direct stimulation was mediated primarily by the activation of interneurons. The results indicate that muscarinic activity 
A

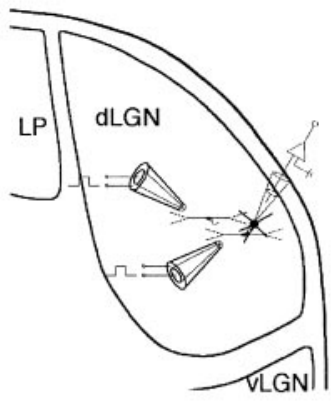

C

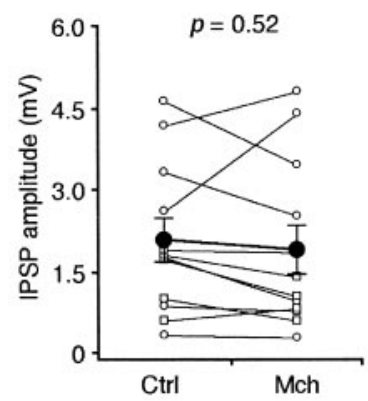

$\mathbf{F}$

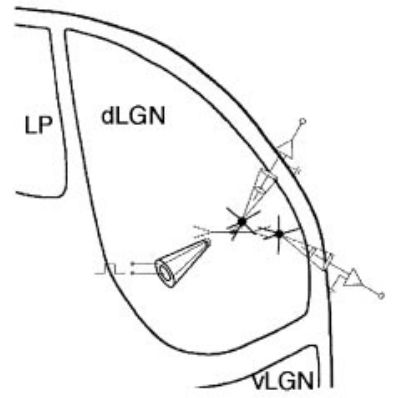

B

Proximal stimulation

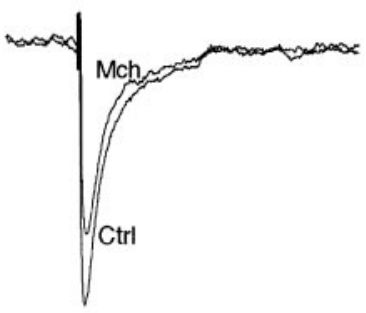

D

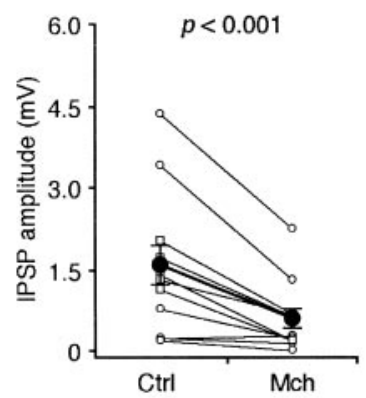

G

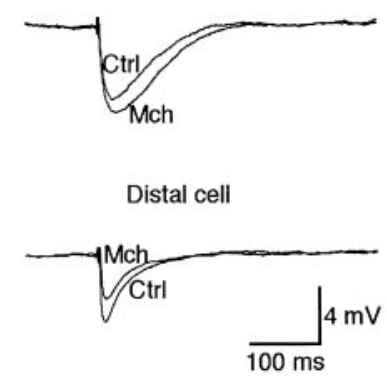

Distal stimulation

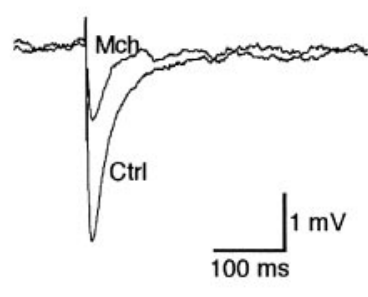

E

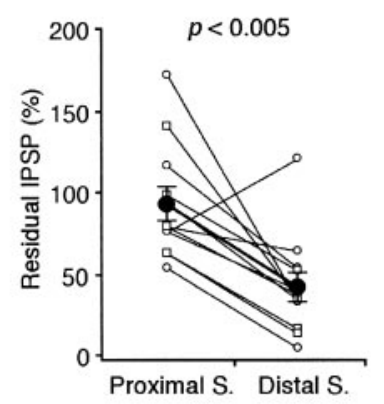

H

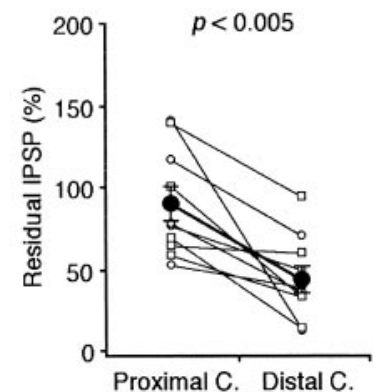

Figure 8. Selective suppression of distal interneuron-mediated $\mathrm{GABA}_{\mathrm{A}}$ inhibition in thalamocortical cells by muscarinic activity. $A$, Schematic drawing of recording and stimulating electrodes indicates the locations of two stimulating electrodes, placed $\sim 250$ and $500 \mu \mathrm{m}$ away from the soma of the recorded thalamocortical cell, respectively. $B$, Direct electric shock at the proximal and distal locations evoked fast IPSPs in a thalamocortical cell in the presence of $5 \mu \mathrm{M}$ NBQX, $100 \mu \mathrm{M}$ DL-AP5, and $1 \mathrm{mM}$ saclofen. The proximal shock-evoked IPSP was less sensitive to the bath application of $1 \mathrm{~mm}$ Mch, compared with the distal shockevoked one. $C$, Amplitude of proximal shock-evoked IPSPs in control or with Mch in bath solution (Ctrl: $2.1 \pm 0.40 \mathrm{mV} ;$ Mch: $1.9 \pm 0.4 \mathrm{mV} ; n=12 ; p=0.52)$. $D$, Amplitude of distal shock-evoked IPSPs in control or with Mch in bath solution (Ctrl: $1.3 \pm 0.4 \mathrm{mV} ;$ Mch: $0.6 \pm 0.2 \mathrm{mV} ; n=12$; $p<0.001)$. E, Relative amplitude of the proximal shock-evoked and distal shockevoked IPSPs with Mch in bath solution (Proximal: $91.0 \pm 10.0 \%$; Distal: $40.3 \pm$ $8.7 \% ; n=12 ; p<0.005)$. The values were normalized to control responses. Note that the muscarinic suppression on distal responses was slightly larger in culture slices than in acute slices (culture: $34.6 \pm 5.5 \%$; $n=6$; acute: $59.6 \pm 22.5 \% ; n=6$; $t$ test; $p=0.29)$. The values were normalized to proximal responses. $F$, Schematic drawing of recording and stimulating electrodes indicates the simultaneous recordings from two thalamocortical cells, located at $\sim 250$ and $500 \mu \mathrm{m}$ away from the stimulating electrode. $G$, Direct electric shock-evoked fast IPSPs in a pair of simultaneously recorded thalamocortical cells in the presence of 5 $\mu \mathrm{M}$ NBQX, $100 \mu \mathrm{M}$ DL-AP5, and $1 \mathrm{~mm}$ saclofen. The IPSP in the proximally located thalamocortical cell was less sensitive to the bath application of $1 \mathrm{~mm}$ Mch, compared with the distally located one. $H$, Relative amplitude of the IPSPs in proximally and distally located thalamocortical cells with Mch in bath solution (Proximal: $89.3 \pm$ 10.3\%; Distal: $43.9 \pm 8.1 \% ; n=10 ; p<$ 0.005). The values were normalized to control responses. Note that the muscarinic suppression on distal responses was slightly larger in culture slices than in acute slices (culture: $44.5 \pm 6.0 \% ; n=5$; acute: $60.1 \pm 9.9 \% ; n=5 ; t$ test; $p=0.37$ ). The values were normalized to proximal responses.

selectively suppresses the distal, interneuron-mediated inhibition but on average has little effect on the local, interneuron-mediated inhibition.

To confirm that Mch selectively suppressed the distal inhibition, we performed another experiment with a slightly modified stimulating and recording setting. In this experiment, only one population of interneurons was stimulated directly. Two thalamocortical cells, located at $\sim 250$ and $500 \mu \mathrm{m}$ away from the stimulating electrode, were then recorded simultaneously (Fig. 8F). Bath application of Mch selectively suppressed the IPSP in the distally located thalamocortical cell, but on average had little effect on that in the proximally located one (Fig. $8 G, H$ ). In fact, the IPSP in the proximally located thalamocortical cells was often boosted by Mch application (Fig. 8G,H). Again, Mch produced a slightly larger (but not significant) suppression on the distal inhibition in culture slices than in acute slices (Fig. $8 H$ ). These results confirm that muscarinic receptor activity selectively suppresses the long-range inhibition.

\section{DISCUSSION}

In this study, we demonstrated that activation of muscarinic receptors in thalamic interneurons switched their firing mode from bursting to tonic. This effect is mediated by the muscarinic subtype 2 receptors and involves enhancement of at least three conductances: a linear potassium conductance, $I_{\mathrm{h}}$, and $I_{\mathrm{CAN}}$. Upregulation of these conductances has little net effect on the resting membrane potential in interneurons but causes a large decrease in their input resistance. The muscarinic activity also effectively modulates the interneuron-mediated inhibition in thalamocortical cells by blocking $\mathrm{GABA}_{\mathrm{B}}$ inhibition, suppressing distal $\mathrm{GABA}_{\mathrm{A}}$ inhibition, and maintaining local $\mathrm{GABA}_{\mathrm{A}}$ inhibition relatively unchanged (Fig. 9).

\section{Muscarinic effect on burst firing in interneurons}

Recently, we have shown that the change of membrane potential can modulate burst firing in interneurons (Zhu et al., 1999a). Here we report a more profound muscarinic effect on input 


\section{Without muscarinic activity}

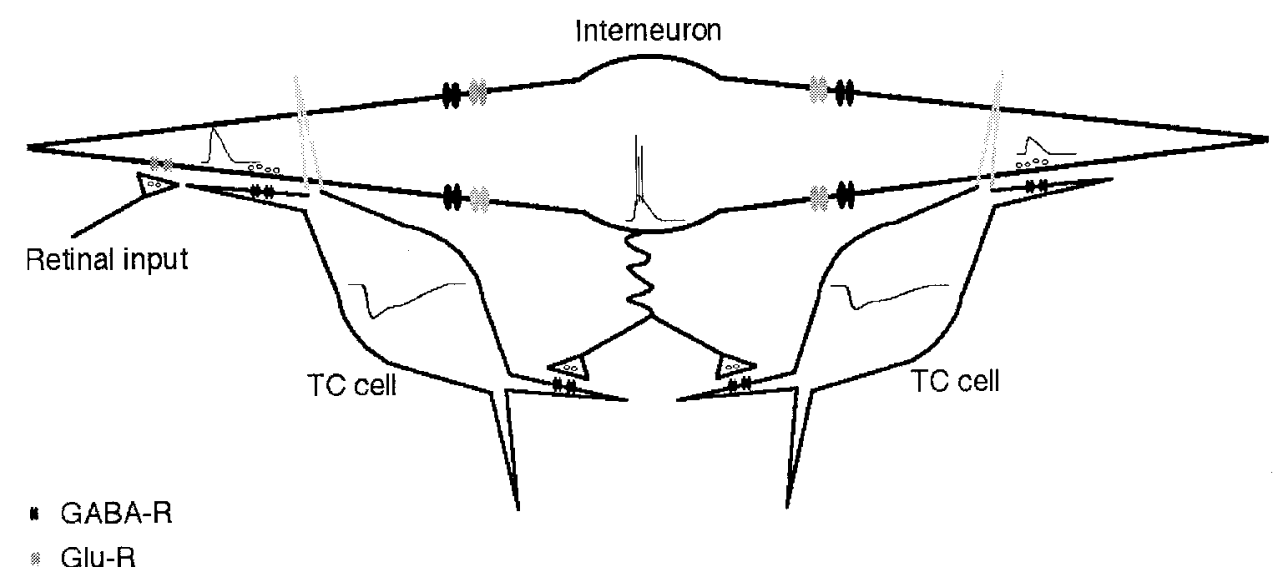

S Glu-P

w $\mathrm{K}^{+}$channel

Cation channel

With muscarinic activity

Figure 9. Schematic drawing shows the patterns of interneuron-mediated inhibition in thalamocortical cells with or without muscarinic activity. Note that the sustained muscarinic activity suppresses long-range, slow dendrite- and axon-originated inhibition, but not local, fast dendrite-originated inhibition in thalamocortical cells caused in part by the muscarinic uncoupling of the distal dendrites of thalamic interneurons.

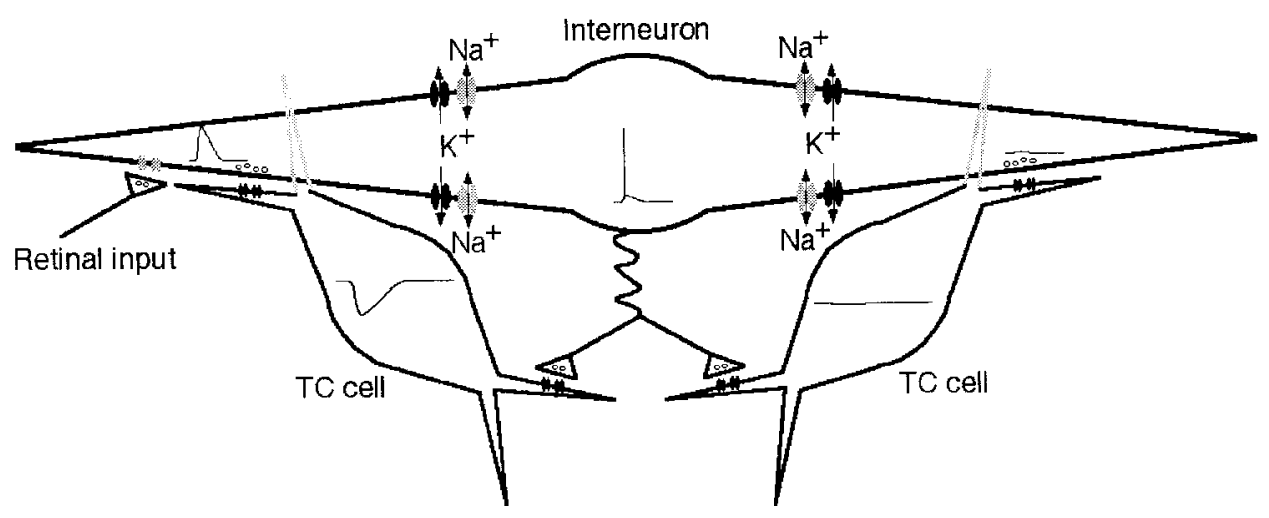

resistance, which can effectively switch the firing mode in these cells. Because thalamus-projecting, cholinergic cells in the brainstem fire tonic action potentials and their firing rate increases during wakefulness (Steriade et al., 1990), we focused on the effect of tonic muscarinic receptor activation, presumably more physiologically relevant, on the membrane properties and firing mode of interneurons in this study. We found that a sustained activation of muscarinic receptors induces a decrease in input resistance and a transformation of firing pattern from bursting to tonic firing. The switch of firing pattern likely results from the decrease in input resistance, which is crucial for interneurons to fire bursts of action potentials (Zhu et al., 1999a). This effect may be mediated by two mechanisms. First, reducing input resistance in interneurons may directly prevent the active conductances from generating large depolarizations necessary for bursting (our unpublished simulation data). Second, reducing input resistance may also indirectly suppress bursting by electrotonically uncoupling the axonal action potential initiation zone from the distal dendrites that appear to host a large amount of active conductances crucial for burst generation in interneurons (Zhu et al., 1999d).

\section{Muscarinic receptor-mediated responses in thalamic interneurons}

An early in vivo study has shown that activation of brainstem cholinergic cells, which project to the thalamic nuclei, can induce a large hyperpolarization in geniculate interneurons (Ahlsén et al., 1984), caused presumably by activation of a potassium conductance (McCormick and Pape, 1988). Here, we show that in addition to a potassium conductance, activation of muscarinic receptors also enhances $I_{\mathrm{h}}$ and $I_{\mathrm{CAN}}$. The discrepancy can be explained by the different recording techniques used. The sharp electrodes used in the previous two studies can cause $\mathrm{Ca}^{2+}$ influx into the cells (Staley et al., 1992), which may subsequently occlude the Mch effects on $I_{\mathrm{h}}$ and $I_{\mathrm{CAN}}$. Consistent with this view, we found that buffering intracellular $\mathrm{Ca}^{2+}$ ions with EGTA selectively blocked the depolarizing currents.

\section{Functional considerations}

Inhibitory neurons can provide many forms of inhibition that are critical for various information processes (Connors et al., 1988; Ferster and Jagadeesh, 1992; Gibson et al., 1999; Huntsman et al., 1999; Anderson et al., 2000; Zhu and Lo, 2000). A tight regulation of the inhibition patterns thus becomes crucially important for the brain to properly perform different tasks (Reyes et al., 1998; Xiang et al., 1998; Finnerty et al., 1999; Larkum et al., 1999). In the thalamus, thalamocortical cells in the lateral posterior (Zhu and Lo, 1997) and lateral geniculate nuclei (Ahlsén et al., 1985; Crunelli et al., 1988; Bal et al., 1995) receive inhibitory inputs from reticular cells. This recurrent inhibition is controlled by neuromodulators, which determine the membrane potentials and firing pattern of reticular cells. However, local thalamic interneurons show little change in their resting membrane potential during the steady- 
state activation of muscarinic receptors. Instead there is a large decrease in input resistance, which effectively switches the firing mode in interneurons from bursting to tonic and changes their electrotonic properties.

A switch of firing pattern from bursting to tonic will suppress $\mathrm{GABA}_{\mathrm{B}}$ inhibition in thalamocortical cells (Huguenard and Prince, 1994; Destexhe and Sejnowski, 1995; Kim et al., 1997). Indeed, the interneuron-mediated $\mathrm{GABA}_{\mathrm{B}}$ response in thalamocortical cells is largely blocked by muscarinic activity, whereas on average the local $\mathrm{GABA}_{\mathrm{A}}$ response changes little. This result is in the line with the previous in vivo finding that activation of brainstem cholinergic cells suppresses only slightly the $\mathrm{GABA}_{\mathrm{A}}$ receptor-mediated inhibition in thalamocortical cells, whereas the $\mathrm{GABA}_{\mathrm{B}}$ receptor-mediated inhibition is completely eliminated (Ahlsén et al., 1984; Hu et al., 1989; Curró Dossi et al., 1992).

The dendrites of thalamic interneurons release the neurotransmitter GABA (Ralston, 1971; Cox et al., 1998). Without the activation of muscarinic receptors, interneurons are likely to be electrotonically compact because of their high input resistance (cf. Zhu, 2000). When muscarinic receptors are activated, the input resistance is reduced by $\sim 50 \%$, and this may isolate their distal dendrites electrotonically from each other (Bloomfield and Sherman, 1989). The distal dendritic triads will function as independent units, being excited by the presynaptic retinal afferents and then directly inhibiting only the postsynaptic dendrites of thalamocortical cells. Thus, we expect that the long-range inhibition (e.g., activation of one distal dendritic terminal and release of GABA at another one) will be suppressed. Our results do show that although the local $\mathrm{GABA}_{\mathrm{A}}$ response remains unchanged after muscarinic receptor activation, the distal $\mathrm{GABA}_{\mathrm{A}}$ response is substantially suppressed. Consistent with this idea, an in vivo study has reported blockade of long-range inhibition in thalamocortical cells by iontophoretic application of acetylcholine in LGN (Eysel et al., 1986).

Because muscarinic activity reduces input resistance and increase electrotonic isolation, the dendrites will become less excitable, and the soma and axon will be more isolated from the dendrites in interneurons (Bloomfield and Sherman, 1989; Zhu, 2000). Thus, the axon will be less sensitive to distal inputs and less likely to reach firing threshold. As expected, muscarinic receptor activation does suppress the axonal firing induced by direct dendritic activation in interneurons, transforming the burst firing into single action potential or subthreshold responses. The notion is further supported by an elegant in vivo report (Curró Dossi et al., 1992), which illustrates that when brainstem cholinergic cells are activated, the $\mathrm{GABA}_{\mathrm{B}}$ receptor-mediated inhibition is completely eliminated. In addition, the axon-mediated $\mathrm{GABA}_{\mathrm{A}}$ inhibition is also substantially suppressed, whereas the dendrite-mediated $\mathrm{GABA}_{\mathrm{A}}$ inhibition is not reduced. Instead, in many instances it is enhanced. Congruent with the observations, the IPSPs resulting from the activation of the distal dendrites are substantially reduced by the muscarinic activity, whereas those caused by the local dendrites are less reduced and sometimes may even be boosted by muscarinic activity.

In addition to muscarinic effects on the intrinsic membrane properties of interneurons, muscarinic activity at presynaptic release sites and postsynaptic thalamocortical cells may also play a role in sharpening the interneuron-mediated inhibition. In the thalamus, although muscarinic receptors are only weakly expressed in some axonal terminals that originate presumably from the cholinergic nuclei in the brainstem, they are highly expressed in the presynaptic dendritic terminals of interneurons (Carden and Bickford, 1999; Plummer et al., 1999). These muscarinic receptors may suppress neurotransmitter release (Gil et al., 1997; Cox and Sherman, 2000) by reducing dendritic excitability (see above discussions) or suppressing the vesicle release machinery, or both. This effect may account for the general suppression of interneuron-mediated $\mathrm{GABA}_{\mathrm{A}}$ responses (also see Curró Dossi et al., 1992; Pape and McCormick 1995). However, the local, dendrite-originated $\mathrm{GABA}_{\mathrm{A}}$ inhibition is not significantly changed by muscarinic activity. This presumably reflects weaker muscarinic suppression of the local, dendrite-originated $\mathrm{GABA}_{\mathrm{A}}$ inhibition, as well as the muscarinic effects on input resistance and membrane potential at postsynaptic thalamocortical cells (McCormick 1992a; Zhu and Uhlrich, 1998), which should amplify the voltage response of $\mathrm{GABA}_{\mathrm{A}}$ current.

\section{Conclusions}

Neuromodulators, including acetylcholine, have been shown to control the firing pattern of several types of neurons by regulating their membrane potential (McCormick, 1992b; Steriade et al., 1997). Here we have demonstrated that acetylcholine can switch the firing patterns in thalamic interneurons, but by a different cellular mechanism. Instead of altering membrane potential, sustained muscarinic activity decreases the input resistance in interneurons. This muscarinic regulation of input resistance provides a new cellular mechanism for in vivo cholinergic suppression of long-range, slow dendrite- and axon-originated inhibition, and boosts local, fast dendrite-originated inhibition in thalamocortical cells (summarized in Fig. 9). The muscarinic promotion of local, fast inhibition should increase both the spatial and temporal resolution of the sensory signals, which is desired for periods of alertness or arousal.

It is now clear that in addition to the axon, the dendrites of a large variety of neurons can release neurotansmitters in an activity-dependent manner (Hausser et al., 1995; MaleticSavatic and Malinow, 1998; Schoppa and Westbrook, 1999; Zilberter et al., 1999; Chen et al., 2000). However, whether the neurotransmitter release at these two sites is coordinated and how it is coordinated are largely unknown. Here, we provide evidence that dendritic and axonal release sites are tightly regulated by muscarinic activity. Our results also show that dendritic compartments of thalamic interneurons can be dynamically coupled and uncoupled, which is presumably dependent on the behavioral states.

\section{REFERENCES}

Ahlsén G, Lindström S, Lo F-S (1984) Inhibition from the brain stem of inhibitory interneurones of the cat's dorsal lateral geniculate nucleus. J Physiol (Lond) 347:593-609.

Ahlsén G, Lindström S, Lo F-S (1985) Interaction between inhibitory pathway to principal cells in the lateral geniculate nucleus of the cat. Exp Brain Res 58:134-143.

Anderson JS, Carandini M, Ferster D (2000) Orientation tuning of input conductance, excitation, and inhibition in cat primary visual cortex. J Neurophysiol 84:909-926.

Bal T, von Krosigk M, McCormick DA (1995) Role of the ferret perigeniculate nucleus in the generation of synchronized oscillations in vitro. J Physiol (Lond) 483:641-663.

Bloomfield SA, Sherman SM (1989) Dendritic current flow in relay cells and interneurons of the cat's lateral geniculate nucleus. Proc Natl Acad Sci USA 86:3911-3914.

Bolz J, Novak N, Staiger V (1992) Formation of specific afferent connections in organotypic slice cultures from rat visual cortex cocultured with lateral geniculate nucleus. J Neurosci 12:3054-3070.

Carden WB, Bickford ME (1999) Location of muscarinic type 2 recep- 
tors within the synaptic circuitry of the cat visual thalamus. J Comp Neurol 410:431-443.

Chen WR, Xiong W, Shepherd GM (2000) Analysis of relations between NMDA receptors and GABA release at olfactory bulb reciprocal synapses. Neuron 25:625-633.

Connors BW, Malenka RC, Silva LR (1988) Two inhibitory postsynaptic potentials, and $\mathrm{GABA}_{\mathrm{A}}$ and $\mathrm{GABA}_{\mathrm{B}}$ receptor-mediated responses in neocortex of rat and cat. J Physiol (Lond) 406:443-468.

Cox CL, Sherman SM (2000) Control of dendritic outputs of inhibitory interneurons in the lateral geniculate nucleus. Neuron 27:597-610.

Cox CL, Zhou Q, Sherman SM (1998) Glutamine locally activates dendritic outputs of thalamic interneurons. Nature 394:478-482.

Crunelli V, Haby M, Jassik-Gerschenfeld D, Leresche N, Pirchio M (1988) $\mathrm{Cl}^{-}$- and $\mathrm{K}^{+}$-dependent inhibitory postsynaptic potentials evoked by interneurones of the rat lateral geniculate nucleus. J Physiol (Lond) 399:153-176.

Curró Dossi R, Pare D, Steriade M (1992) Various types of inhibitory postsynaptic potentials in anterior thalamic cells are differentially altered by stimulation of laterodorsal tegmental cholinergic nucleus. Neuroscience 47:279-289.

Deschênes M, Paradis M, Roy JP, Steriade M (1984) Electrophysiology of neurons of lateral thalamic nuclei in cat: resting properties and burst discharges. J Neurophysiol 51:1196-1219.

Destexhe A, Sejnowski TJ (1995) G protein activation of kinetics and spillover of $\gamma$-aminobutyric acid may account for differences between inhibitory responses in the hippocampus and thalamus. Proc Natl Acad Sci USA 92:9515-9519.

Eysel UT, Pape H-C, Van Schayck R (1986) Excitatory and differential disinhibitory actions of acetylcholine in the lateral geniculate nucleus of the cat. J Physiol (Lond) 370:233-254.

Ferster D, Jagadeesh B (1992) EPSP-IPSP interactions in cat visual cortex studied with in vivo whole-cell patch recording. J Neurosci 12:1262-1274.

Finnerty GT, Roberts LS, Connors BW (1999) Sensory experience modifies the short-term dynamics of neocortical synapses. Nature 400:367-371.

Francesconi W, Müller CM, Singer W (1988) Cholinergic mechanisms in the reticular control of transmission in the cat lateral geniculate nucleus. J Neurophysiol 59:1690-1718.

Gabbott PLA, Somogyi J, Stewart MG, Hamori J (1986) A quantitative investigation of the neuronal composition of the rat dorsal lateral geniculate nucleus using GABA-immunocytochemistry. Neuroscience 19:101-111.

Gibson JR, Beierlein M, Connors BW (1999) Two networks of electrically coupled inhibitory neurons in neocortex. Nature 402:75-79.

Gil Z, Connors BW, Amitai Y (1997) Differential regulation of neocortical synapses by neuromodulators and activity. Neuron 19:679-686.

Hagiwara N, Irisawa H (1989) Modulation by intracellular $\mathrm{Ca}^{2+}$ of the hyperpolarization-activated inward current in rabbit single sino-atrial node cells. J Physiol (Lond) 409:121-141.

Hartveit E, Heggelund P (1993) The effect of acetylcholine on the visual response of lagged cells in the cat dorsal lateral geniculate nucleus. Exp Brain Res 95:443-449.

Hartveit E, Heggelund P (1994) Response variability of single cells in the dorsal lateral geniculate nucleus of the cat. Comparison with retinal input and effect of brain stem stimulation. J Neurophysiol 72:1278-1289.

Hartveit E, Heggelund P (1995) Brainstem modulation of signal transmission through the cat dorsal lateral geniculate nucleus. Exp Brain Res 103:372-384.

Hartveit E, Ramberg SI, Heggelund P (1993) Brain stem modulation of spatial receptive field properties of single cells in the dorsal lateral geniculate nucleus of the cat. J Neurophysiol 70:1644-1655.

Hausser M, Stuart G, Racca C, Sakmann B (1995) Axonal initiation and active dendritic propagation of action potentials in substantia nigra neurons. Neuron 15:637-647.

Helmchen F, Imoto K, Sakmann B (1996) $\mathrm{Ca}^{2+}$ buffering and action potential-evoked $\mathrm{Ca}^{2+}$ signaling in dendrites of pyramidal neurons. Biophys J 70:1069-1081.

Hu B, Steriade M, Deschênes M (1989) The effects of brainstem peribrachial stimulation on neurons of the lateral geniculate nucleus. Neuroscience 31:13-24.

Huguenard JR (1996) Low-threshold calcium currents in central nervous system neurons. Annu Rev Physiol 58:329-348.

Huguenard JR, Prince DA (1994) Clonazepam suppresses $\mathrm{GABA}_{\mathrm{B}^{-}}$ mediated inhibition in thalamic relay neurons through effects in nucleus reticularis. J Neurophysiol 71:2576-2581.

Huntsman MM, Porcello DM, Homanics GE, DeLorey TM, Huguenard JR (1999) Reciprocal inhibitory connections and network synchrony in the mammalian thalamus. Science 283:541-543.

Kim U, Sanchez-Vives MV, McCormick DA (1997) Functional dynamics of GABAergic inhibition in the thalamus. Science 278:130-134.

Larkum ME, Zhu JJ, Sakmann B (1999) A new cellular mechanism for coupling inputs arriving at different cortical layers. Nature 398:338-341.

Lechleiter J, Girard S, Clapham D, Peralta E (1991) Subcellular patterns of calcium release determined by $\mathrm{G}$ protein-specific residues of muscarinic receptors. Nature 350:505-508.

Luthi A, McCormick DA (1999) Modulation of a pacemaker current through $\mathrm{Ca}^{2+}$-induced stimulation of cAMP production. Nat Neurosci 2:634-641.

Maletic-Savatic M, Malinow R (1998) Calcium-evoked dendritic exocytosis in cultured hippocampal neurons. Part I: trans-Golgi networkderived organelles undergo regulated exocytosis. J Neurosci 18:6803-6813.

McCormick DA (1992a) Cellular mechanisms underlying cholinergic and noradrenergic modulation of neuronal firing mode in the cat and guinea pig dorsal lateral geniculate nucleus. J Neurosci 12:278-289.

McCormick DA (1992b) Neurotransmitter actions in the thalamus and cerebral cortex and their role in neuromodulation of thalamocortical activity. Prog Neurobiol 39:337-388.

McCormick DA, Pape H-C (1988) Acetylcholine inhibits identified interneurons in the cat lateral geniculate nucleus. Nature 334:246-248.

McKinney RA, Luthi A, Bandtlow CE, Gahwiler BH, Thompson SM (1999) Selective glutamate receptor antagonists can induce or prevent axonal sprouting in rat hippocampal slice cultures. Proc Natl Acad Sci USA 96:11631-11636.

Michel AD, Delmendo RE, Lopez M, Whiting RL (1990) On the interaction of gallamine with muscarinic receptor subtypes. Eur J Pharmacol 182:335-345

Murphy PC, Uhlrich DJ, Tamamaki N, Sherman SM (1994) Brain-stem modulation of the response properties of cells in the cat's perigeniculate nucleus. Vis Neurosci 11:781-791.

Ohara PT, Sefton AJ, Lieberman AR (1980) Mode of termination of afferents from the thalamic reticular nucleus in the dorsal lateral geniculate nucleus of the rat. Brain Res 197:503-506.

Ohara PT, Lieberman AR, Hunt SP, Wu J-Y (1983) Neural elements containing glutamic acid decarboxylase (GAD) in the dorsal lateral geniculate nucleus of the rat: immunohistochemical studies by light and electron microscopy. Neuroscience 8:189-244.

Ottersen OP, Storm-Mathisen J (1984) Glutamine- and GABAcontaining neurons in the mouse and rat brain, as demonstrated with a new immunocytochemical technique. J Comp Neurol 229:374-392.

Pape H-C, McCormick DA (1995) Electrophysiological and pharmacological properties of interneurons in the cat dorsal lateral geniculate nucleus. Neuroscience 68:1105-1125.

Pape H-C, Budde T, Mager R, Kisvarday ZF (1994) Prevention of $\mathrm{Ca}^{2+}$-mediated action potentials in GABAergic local circuit neurones of rat thalamus by a transient $\mathrm{K}^{+}$current. J Physiol (Lond) 478:403-422

Paré D, Curró Dossi R, Steriade M (1991) Three types of inhibitory postsynaptic potentials generated by interneurons in the anterior thalamic complex of cat. J Neurophysiol 66:1190-1204.

Plummer KL, Manning KA, Levey AI, Rees HD, Uhlrich DJ (1999) Muscarinic receptor subtypes in the lateral geniculate nucleus: a light and electron microscopic analysis. J Comp Neurol 404:408-425.

Ralston III HJ (1971) Evidence for presynaptic dendrites and a proposal for their mechanism of action. Nature 230:585-588.

Reyes A, Lujan R, Rozov A, Burnashev N, Somogyi P, Sakmann B (1998) Target-cell-specific facilitation and depression in neocortical circuits. Nat Neurosci 1:279-285.

Schoppa NE, Westbrook GL (1999) Regulation of synaptic timing in the olfactory bulb by an A-type potassium current. Nat Neurosci 2:1106-1113

Sherman SM, Guillery RW (1996) Functional organization of thalamocortical relays. J Neurophysiol 76:1367-1395.

Sieg F, Obst K, Gorba T, Riederer B, Pape H-C, Wahle P (1998) Postnatal expression pattern of calcium-binding proteins in organotypic thalamic cultures and in the dorsal thalamus in vivo. Dev Brain Res 110:83-95.

Sillito AM, Kemp JA, Beradi N (1983) The cholinergic influence on the function of cat dorsal lateral geniculate nucleus (dLGN). Brain Res 280:299-307.

Staley KJ, Otis TS, Mody I (1992) Membrane properties of dentate gyrus granule cells: comparison of sharp microelectrode and whole-cell recordings. J Neurophysiol 67:1346-1358.

Steriade M, Pare D, Datta S, Oakson G, Curro Dossi R (1990) Different cellular types in mesopontine cholinergic nuclei related to pontogeniculo-occipital waves. J Neurosci 10:2560-2579.

Steriade M, Contreras D, Amzica F, Timofeev I (1996) Synchronization of fast $(30-40 \mathrm{~Hz})$ spontaneous oscillations in intrathalamic and thalamocortical networks. J Neurosci 16:2788-2808.

Steriade M, Jones EG, McCormick DA (1997) Thalamus. Amsterdam: Elsevier Science.

Uhlrich DJ, Tamamaki N, Murphy PC, Sherman SM (1995) Effects of brain stem parabrachial activation on receptive field properties of cells in the cat's lateral geniculate nucleus. J Neurophysiol 73:2428-2447.

Webster MJ, Rowe MH (1984) Morphology of identified relay cells and interneurons in the dorsal lateral nucleus of the rat. Exp Brain Res $56: 468-474$.

Williams SR, Turner JP, Anderson CM, Crunelli V (1996) Electrophys- 
iological and morphological properties of interneurones in the rat dorsal lateral geniculate nucleus in vitro. J Physiol (Lond) 490:129-147.

Xiang Z, Huguenard JR, Prince DA (1998) Cholinergic switching within neocortical inhibitory networks. Science 281:985-988.

Zhu JJ (2000) Maturation of layer 5 neocortical pyramidal neurons: amplifying salient layer 1 and layer 4 inputs by $\mathrm{Ca}^{2+}$-action potentials in adult rat tuft dendrites. J Physiol (Lond) 526:571-587.

Zhu JJ, Lo F-S (1997) Recurrent inhibitory interneurons of the rabbit's lateral posterior-pulvinar complex. J Neurophysiol 78:3117-3124.

Zhu JJ, Lo F-S (1998) Control of recurrent inhibition of the lateral posterior-pulvinar complex by afferents from the deep layers of the superior colliculus of the rabbit. J Neurophysiol 80:1122-1131.

Zhu JJ, Lo F-S (1999) Three GABA receptor-mediated postsynaptic potentials in interneurons in the rat lateral geniculate nucleus. J Neurosci 19:5721-5730.

Zhu JJ, Lo F-S (2000) Recurrent inhibitory circuitry in the deep layers of the rabbit superior colliculus. J Physiol (Lond) 523:731-740.

Zhu JJ, Uhlrich DJ (1997) Nicotinic receptor-mediated responses in relay cells and interneurons in the rat lateral geniculate nucleus. Neuroscience 80:191-202.
Zhu JJ, Uhlrich DJ (1998) Cellular mechanisms underlying two muscarinic receptor-mediated depolarizing responses in relay cells of the rat lateral geniculate nucleus. Neuroscience 87:767-781.

Zhu JJ, Lytton WW, Xue J-T, Uhlrich DJ (1999a) An intrinsic oscillation in interneurons of the rat lateral geniculate nucleus. J Neurophysiol $81: 702-711$

Zhu JJ, Uhlrich DJ, Lytton WW (1999b) Properties of a hyperpolarization-activated cation current in interneurons in the rat lateral geniculate nucleus. Neuroscience 92:445-457.

Zhu JJ, Sakmann B, Heggelund P (1999c) Postnatal development of intrinsic bursting and morphology of interneurons in the rat dorsal lateral geniculate nucleus. Soc Neurosci Abstr 25:1425.

Zhu JJ, Uhlrich DJ, Lytton WW (1999d) Burst firing in identified rat geniculate interneurons. Neuroscience 92:1445-1460.

Zhu JJ, Esteban JA, Hayashi Y, Malinow R (2000) Postnatal synaptic potentiation: delivery of GluR4-containing AMPA receptors by spontaneous activity. Nat Neurosci 3:1098-1106.

Zilberter Y, Kaiser KM, Sakmann B (1999) Dendritic GABA release depresses excitatory transmission between layer $2 / 3$ pyramidal and bitufted neurons in rat neocortex. Neuron 24:979-988. 